Revista Brasil. Bot., V.28, n.1, p.171-178, jan.-mar. 2005

\title{
Flowering phenology, seed set and arthropod guilds in Trichogoniopsis adenantha (DC) (Asteraceae) in south-east Brazil ${ }^{1}$
}

\author{
GUSTAVO Q. ROMERO ${ }^{2,3}$ and JOÃO VASCONCELLOS NETO²
}

(received: February 5, 2004; accepted: November 18, 2004)

\begin{abstract}
Flowering phenology, seed set and arthropod guilds in Trichogoniopsis adenantha (DC) (Asteraceae) in south-east Brazil). Trichogoniopsis adenantha (Asteraceae) is a shrub plant that inhabits forest margins and glades. This species blooms throughout the year, attracting arthropods of various guilds, including herbivores, pollinators and predators. In this study, done over a two year period, we described the phenology of T. adenantha and assessed the seasonal variation in arthropod numbers of different guilds. We also determined the periods of lowest and highest seed set. T. adenantha population showed a peak in flowering in March-April (rainy season) with greater production of achenes in December-April. April and October had respectively highest and lowest number of fertilized, undamaged ovules, and this pattern is possibly related with population dynamics of pollinators and herbivores. In August, which was the period of greatest damage to the stigma (by geometrid larvae), there was a positive relationship between the proportion of unfertilized ovules and flowers with damaged stigma, suggesting that floral herbivory may affect reproduction in T. adenantha. We discuss the complex dynamics of the beneficial and harmful interactions between arthropods and the host plant.
\end{abstract}

Key words - animal-plant interactions, floral herbivory, pollination, population dynamics, pre-dispersal seed predation

RESUMO - (Fenologia floral, produção de sementes e guildas de artrópodes em Trichogoniopsis adenantha (DC) (Asteraceae) no sudeste do Brasil). Trichogoniopsis adenantha (Asteraceae) é uma planta arbustiva que habita margens de florestas e clareiras. Esta espécie se reproduz durante o ano todo, atraindo artrópodes de várias guildas, incluindo herbívoros, polinizadores e predadores. Neste estudo, feito em um período de mais de dois anos, descrevemos a fenologia de T. adenantha e avaliamos a variação sazonal no número de artrópodes de diferentes guildas. Também determinamos os períodos de maior e menor produção de sementes. A população de T. adenantha apresentou pico de floração em março-abril (período chuvoso) com maior produção de aquênios em dezembro-abril. Abril e outubro tiveram respectivamente maior e menor número de óvulos fertilizados e não danificados, e este padrão possivelmente está relacionado com a dinâmica das populações dos polinizadores e herbívoros. Em agosto, período de maior danos aos estigmas (por larvas de geometrídeos), houve uma relação positiva entre a proporção de óvulos não fertilizados e flores com estigmas danificados, sugerindo que herbivoria floral pode afetar a reprodução em T. adenantha. Discutimos a dinâmica complexa das interações benéficas e prejudiciais entre artrópodes e sua planta hospedeira.

Palavras-chave - dinâmica de populações, herbivoria floral, interações animal-planta, polinização, predação pré-dispersão de sementes

\section{Introduction}

Reproductive rates in plants can be affected by various factors, such as water stress, light intensity, nutrient availability (Hamilton et al. 1999, McKenna \& Houle 2000), seed fertilization (Stephenson 1981, Mamood et al. 1990, Cabrera \& Dieringer 1992, Olsen 1997, Ehlers 1999, Roitman 1999) and pre-dispersal predation of the seeds (Janzen 1971, Louda 1982,

\footnotetext{
1. Parte integrante da dissertação de mestrado de G.Q. Romero, no Programa de Pós-graduação em Ecologia, Instituto de Biologia, Universidade Estadual de Campinas.

2. Universidade Estadual de Campinas, Instituto de Biologia, Departamento de Zoologia, Caixa Postal 6109, 13083-970 Campinas, SP, Brasil.

3. Corresponding author: gq_romero@yahoo.com.br
}

Maddox et al. 1991, Greig 1993, Sheppard et al. 1994, Louda \& Potvin 1995, Ehrlén 1996, Calvo Irabién \& Islas Luna 1999). Some studies have shown that predispersal seed predation limits the recruiting and sapling abundance of Haplopappus squarrosus and Cirsium canescens (Asteraceae) (Louda 1982, Louda \& Potvin 1995), and can exert a selective pressure on the floral phenology of Helianthus annuus (Asteraceae) (Pilson 2000). Herbivory on floral tissues can make the flowers less attractive for pollinators, and thereby influence the reproductive rates of the plant (Lehtilä \& Strauss 1997, Krupnick et al. 1999, Mothershead \& Marquis 2000).

Trichogoniopsis adenantha DC. (Asteraceae) is a shrub species that inhabits forest margins and glades of south-east Brazil. The species flowers throughout the year (Romero \& Vasconcellos Neto 2003, 2004a, b), providing an abundant and continuous resource for herbivores, floral visitors, and indirectly for predators. 
The purposes of this study were to describe: 1) the floral and vegetative phenology, 2) the seasonal variation in a) arthropod fauna, b) capitula infestation, c) investment in achene production, and 3) the indirect influence of floral herbivory on seed set.

\section{Material and methods}

Study area - This study was done along the margins of the Mirante track, at an altitude of $1,170 \mathrm{~m}$, in the Serra do Japi $\left(23^{\circ} 11^{\prime} \mathrm{S}\right.$ and $\left.46^{\circ} 52^{\prime} \mathrm{W}\right)$, close to Jundiaí city, in south-east Brazil. The climate is seasonal, with hot, moist summers (November-April), and cold, dry winters (May-October) (Pinto 1992). The local vegetation is characterized by high elevation semideciduous forest, with canopy height varying between 10-15 m, and very dense undergrowth (Leitão Filho 1992).

Flowering phenology - To study the T. adenantha phenology in the field, we randomly inspected 17 to 26 plants every fortnight, from April 1998 to March 2000. In each plant, we recorded the number of vegetative and reproductive branches, the number of capitula per branch, and plant height. We recorded in situ the phenophases of the capitula on each of the reproductive branches. These phenophases were classified as: 1) buds with flowers enclosed by bracts (bud phase), 2) buds with still closed corollas (pre-anthesis phase), 3) open corollas (anthesis phase), 4) yellow flowers with pending stigmas (pre-dispersal phase), 5) withered flowers and dispersing achenes (dispersal phase). The reproductive branches were classified according to the predominant $(\geq 50 \%)$ capitula type. When equal numbers of capitula of different phenophases occurred on the same branch, the branches were classified according to the most advanced phenophase.

Seasonal fluctuation of arthropod guilds on T. adenanthaTo assess the seasonal fluctuation of arthropod guilds on T. adenantha, we censused all the arthropods found on 45 to 65 plants from December 1998 to March 2000 along the Mirante track during 1 hour of fortnight observations, between 10:00 a.m. and 12:00 p.m. (two times between 12:00 and 1:30 p.m.) of sunny days, the time period when most pollinators occur (G. Q. Romero \& J. Vasconcellos Neto, unpublished data). Thrips (Thysanoptera) were not censused, since they live inside capitula and were very tiny. The arthropods that presented field identification problems were collected and identified in the laboratory.

Infestation rates and viable achene production - To evaluate the herbivore infestation in $T$. adenantha capitula, the seasonal variations in achene production and the number of predated or undamaged-fertilized ovules, we collected monthly or bimonthly from $60 \%$ to $100 \%$ of the capitula in the predispersal phenophase of 20 plants randomly chosen (most of them were used to assess the flowering phenology). The capitula were collected from January to December 1999 and then kept separately until emergence of the endophages. After the capitula have been subsequently dried, we counted the number of fertilized-undamaged (viable) and fertilizeddamaged ovules (both dark gray to black color) and unfertilizedundamaged and unfertilized-damaged ovules (both not viables, white to cream color). In greenhouses where there were no floral visitors, the ovules were not fertilized (G.Q. Romero, unpublished data), indicating that the plant requires an external agent for ovule fertilization. We also registered the number of flowers with eaten or undamaged stigmas and the causal agents of the damage on the dried material.

When the capitula were heavily damaged, we counted the number of scars in the floral receptacle in order to assess the number of existing achenes. In the absence of adult endophages, their occurrence was recorded based on the presence of puparia. Trupanea sp. (Diptera, Tephritidae) has black and opaque puparia, and Melanagromyza sp. (Diptera, Agromyzidae) has clear (cream colored) and translucent puparia (Romero \& Vasconcellos Neto 2004b). The damage to achenes caused by Geometridae spp. (Lepidoptera) was characterized by a totally or partially eaten pappus, and progressed downwards from the pappus to the base (floral receptacle) of the achene.

Statistical analyses - All data involving proportions were arcsin square root transformed to approach a normal distribution and to equalize the variances, and then compared by one-way ANOVA or t-test. However, only non-transformed data were used in the graphic representations. The ratio of fertilized-undamaged ovules to the total number of achenes (or ovules) was obtained using only non-infested capitula, since floral herbivory can interfere with the fertilization rate. Pearson's correlation (Zar 1996) was used to determine whether the production of reproductive branches and achenes by $T$. adenantha was affected by rainfall and temperature. The temperature and rainfall data were obtained from the Jundiaí Experimental Station (JES) located $8 \mathrm{~km}$ from the study area, at an altitude of $710 \mathrm{~m}$. The temperature data were adjusted for the study area, by subtracting $0.6{ }^{\circ} \mathrm{C}$ for each $100 \mathrm{~m}$ of elevation (Ogden \& Powell 1979). Hence, for the Mirante track $(1,170 \mathrm{~m}$ alt. $), 2.76^{\circ} \mathrm{C}$ were subtracted from the original data. Since Pinto (1992) showed that precipitation did not vary among some places of different elevations in the Serra do Japi, the same data of rainfall obtained from JES were considered to the local of study area.

\section{Results}

Flowering phenology - Trichogoniopsis adenantha produced up to seven capitula per branch, but with desynchronized development, with the same branch often having capitula in different phenophases. The capitula required on average 32 days to complete their development.

The periods of greatest branch production (number) occurred between September and November 1998 and between June 1999 and January 2000 (figure 1A). Most 
of the increase in the number of branches resulted from a rise in the number of vegetative branches, which were generally more abundant than reproductive branches, except from February to April 1999 and March 2000, when the ratio was approximately 1:1 (figure 1A). From December to May (or June), there was a greater proportion of branches with capitula, mainly in bud and pre-dispersal phase, compared to the other periods of the year, and in March-April the number of these branches peaked. Pre-anthesis, anthesis, and dispersal branches were more stable (varied less in proportion) through time, but were less frequent than the other branches (figure 1B).

The variation in the abundance of reproductive branches was positively correlated with rainfall $(r=0.44$; $\mathrm{n}=24 ; \mathrm{P}=0.03$ ), but there is no evidence to consider that $T$. adenantha plants are producing a greater number of capitula during the period of higher rainfall $(\mathrm{r}=0.38$; $\mathrm{n}=24 ; \mathrm{P}=0.070$ ).

Seasonal fluctuation of arthropod guilds on T. adenantha - The most common endophage herbivores of capitula
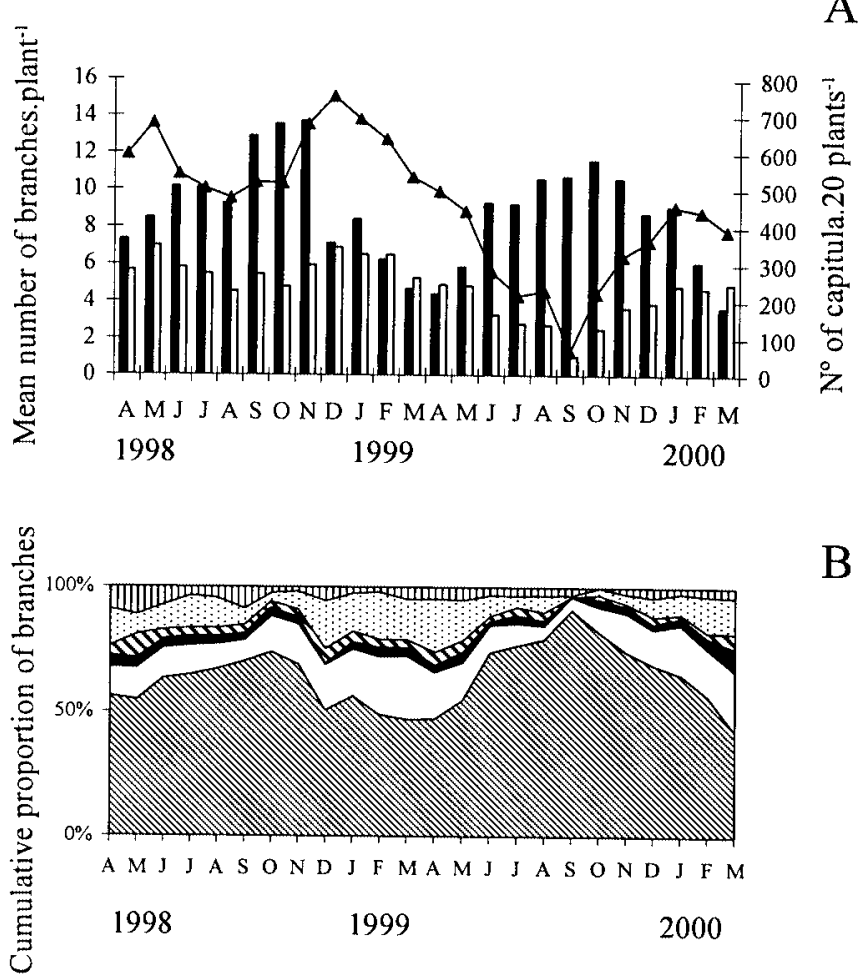

Figure 1. A. Seasonal variation in the mean production of vegetative ( $\boldsymbol{\square}$ ) and reproductive branches ( $\square$ ) of Trichogoniopsis adenantha, and number of capitula produced per 20 plants $\left(-\Delta_{-}\right)$. B. Cumulative proportion of vegetative $(\mathbb{Q})$ and reproductive branches in different phenophases (bud $=\square$; pre-anthesis $=\square$; anthesis $=\mathbb{\Delta}$; predispersal $=$ : ; dispersal $=$ 面) between April 1998 and March 2000 , in Mirante track, Serra do Japi. of this plant were Melanagromyza sp. and Trupanea sp. Geometridae spp. larvae were the main exophage herbivores. The most frequent floral visitors were Pseudoscada erruca, Episcada carcinia, Aeria olena (Lepidoptera, Nymphalidae, Ithomiinae), Ctenuchinae spp. (Lepidoptera, Arctiidae), Syrphidae spp. (Diptera) and Apoidea spp. (Hymenoptera) (table 1). Mechanitis polymnia, M. lysimnia and Epityches eupompe (Lep., Nymphalidae, Ithomiinae) were also observed.

The herbivore populations were highest in the rainy period from November to February 2000 and lowest in the dry period from June to September 1999. The population of the main endophage (Melanagromyza sp.) was high between November 1999 and March 2000. Geometridae spp. larvae occurred almost the whole year, but with a peak in April. Floral visitors (potential pollinators) occurred in higher frequency from December 1998 to May 1999, and practically disappeared from June to November. The unique insect species that occurred in higher frequency on plants in the dry, cold season (April-September) was the predator Reduvidae sp., with a peak in July-August (table 1).

Infestation rate and viable achene production - Five hundred and ninety capitula were collected to determine the infestation rates and seasonal variation in viable achene production. The mean height of the plants from which capitula were collected did not vary significantly along the year $\left(\mathrm{F}_{6,129}=0.60 ; \mathrm{P}=0.73\right)$.

While the endophage Trupanea sp. infested capitula in higher frequency in January (16.7\%), Melanagromyza sp. infested capitula in higher frequency in October (67.5\%). In contrast, Geometridae spp. infested capitula in higher frequency in June (27.7\%, table 2). The higher co-occurrence of herbivores in the capitula occurred in December (16.9\%, table 2).

Trichogoniopsis adenantha individuals produced from 22 to 68 achenes per capitulum. The number of achenes per capitulum varied throughout the months of $1999\left(\mathrm{~F}_{6,590}=8.14 ; \mathrm{P}<0.0001\right)$. On average, the lowest number of achenes per capitulum occurred between April and October, with the lowest production in August (figure 2). These months correspond to the cold periods with the least rainfall. There was a positive relationship between temperature and achene production $(r=0.89$; $\mathrm{F}=20.2 ; \mathrm{n}=7 ; \mathrm{P}=0.006$ ), but a marginal relationship between achene production and rainfall $(\mathrm{r}=0.75$; $\mathrm{F}=6.31 ; \mathrm{n}=7 ; \mathrm{P}=0.053)$.

The mean number of unfertilized, undamaged ovules varied significantly among the months of 1999 $\left(\mathrm{F}_{6,590}=19.98 ; \mathrm{P}<0.0001\right)$, and was higher in January and from June to October. The number of unfertilized, 
damaged ovules differed among the months $\left(\mathrm{F}_{6,590}=20.53 ; \mathrm{P}<0.001\right)$ and was higher in October and December (figure 2). The mean number of fertilized, undamaged (viable) ovules varied significantly among the months of $1999\left(\mathrm{~F}_{6,590}=26.49 ; \mathrm{P}<0.0001\right)$, with the higher and lower proportion of viable achenes occurring in April and October, respectively. The number of fertilized-damaged ovules that was very low, when

Table 1. Arthropods seasonal numerical variation which compounds associated guilds to Trichogoniopsis adenantha (Asteraceae), between December 1998 and March 2000, in Mirante track, Serra do Japi.

Periods of observation (months)

Guilds

Dec Jan Feb Mar Apr May Jun Jul Aug Sep Oct Nov Dec Jan Feb Mar TOTAL

\section{HERBIVORES}

Endophages

\begin{tabular}{|c|c|c|c|c|c|c|c|c|c|c|c|c|c|c|c|c|c|}
\hline Melanagromyza sp. (Dip.) & 9 & 19 & 12 & 10 & 6 & 3 & 0 & 2 & 9 & 2 & 1 & 15 & 13 & 12 & 16 & 7 & 136 \\
\hline Xantaciura sp. (Dip.) & 9 & 0 & 0 & 0 & 0 & 0 & 0 & 0 & 0 & 0 & 1 & 0 & 12 & 4 & 0 & 0 & 26 \\
\hline \multicolumn{18}{|l|}{ Suckers } \\
\hline Miridae sp.1 (Hem.) & 10 & 8 & 20 & 20 & 24 & 48 & 10 & 12 & 6 & 7 & 7 & 34 & 45 & 32 & 40 & 22 & 345 \\
\hline Miridae sp.2(Hem.) & 5 & 3 & 1 & 2 & 2 & 2 & 2 & 0 & 0 & 0 & 0 & 1 & 5 & 2 & 3 & 1 & 29 \\
\hline Aphididae spp. (Hom.) & 0 & 4 & 1 & 0 & 0 & 0 & 1 & 5 & 7 & 1 & 8 & 36 & 3 & 8 & 2 & 10 & 86 \\
\hline Hoppers (Hom.) & 0 & 0 & 1 & 2 & 5 & 3 & 2 & 9 & 5 & 15 & 13 & 4 & 3 & 4 & 4 & 3 & 73 \\
\hline \multicolumn{18}{|l|}{ Chewers } \\
\hline Geometridae spp. (larva) (Lep.) & 10 & 10 & 10 & 4 & 37 & 12 & 12 & 5 & 4 & 0 & 2 & 0 & 7 & 10 & 3 & 5 & 131 \\
\hline Grillidae sp. (Orth.) & 1 & 5 & 2 & 0 & 2 & 2 & 1 & 2 & 3 & 2 & 1 & 2 & 1 & 1 & 2 & 3 & 30 \\
\hline Chrysomelidae spp. (Col.) & 2 & 3 & 1 & 5 & 1 & 2 & 1 & 1 & 2 & 7 & 11 & 0 & 1 & 6 & 0 & 4 & 47 \\
\hline \multicolumn{18}{|l|}{ LORAL VISITORS } \\
\hline Ithomiinae spp. (Lep.) & 20 & 6 & 8 & 10 & 11 & 7 & 0 & 0 & 0 & 0 & 0 & 0 & 1 & 2 & 8 & 6 & 79 \\
\hline Syrphidae spp. (Dip.) & 2 & 5 & 3 & 0 & 0 & 0 & 0 & 0 & 0 & 0 & 0 & 0 & 0 & 1 & 2 & 0 & 13 \\
\hline Apoidea spp. (Hym.) & 1 & 2 & 0 & 0 & 0 & 0 & 0 & 0 & 1 & 1 & 2 & 1 & 1 & 4 & 2 & 0 & 15 \\
\hline Ctenuchinae spp. (Lep.) & 0 & 0 & 0 & 0 & 0 & 0 & 0 & 0 & 0 & 0 & 0 & 1 & 1 & 1 & 6 & 1 & 10 \\
\hline \multicolumn{18}{|l|}{ PARASITOIDS } \\
\hline Braconidae spp. (Hym.) & 7 & 4 & 6 & 5 & 9 & 4 & 0 & 2 & 3 & 2 & 1 & 1 & 3 & 0 & 2 & 3 & 52 \\
\hline Pteromalidae spp. (Hym.) & 15 & 8 & 3 & 2 & 3 & 2 & 0 & 0 & 5 & 2 & 2 & 4 & 7 & 4 & 1 & 3 & 61 \\
\hline \multicolumn{18}{|l|}{ PREDATORS } \\
\hline Reduviidae sp. (Hem.) & 0 & 3 & 3 & 5 & 8 & 12 & 16 & 33 & 32 & 21 & 19 & 4 & 1 & 1 & 6 & 3 & 167 \\
\hline Araneae spp. (Arach.) & 5 & 6 & 3 & 4 & 1 & 0 & 0 & 0 & 0 & 10 & 8 & 4 & 7 & 12 & 8 & 5 & 73 \\
\hline Formicidae spp. (Hym.) & 0 & 0 & 0 & 4 & 2 & 9 & 1 & 5 & 5 & 5 & 16 & 8 & 10 & 12 & 3 & 7 & 87 \\
\hline \multicolumn{18}{|l|}{ EVENTUALS } \\
\hline Chironomidae spp. (Dip.) & 0 & 1 & 0 & 2 & 0 & 0 & 0 & 0 & 0 & 0 & 4 & 5 & 0 & 2 & 0 & 2 & 16 \\
\hline Muscoidea spp. (Dip.) & 0 & 1 & 8 & 20 & 5 & 0 & 4 & 10 & 2 & 2 & 3 & 2 & 0 & 4 & 14 & 20 & 95 \\
\hline ГOTAL & 101 & 88 & 85 & 100 & 119 & 107 & 50 & 86 & 84 & 78 & 100 & 123 & 124 & 126 & 124 & 105 & 1600 \\
\hline
\end{tabular}

Table 2. Trichogoniopsis adenantha capitula infestation by Trupanea sp. (Diptera, Tephritidae), Melanagromyza sp. (Diptera, Agromyzidae) and Geometridae spp. (Lepidoptera) herbivores in 1999, in Mirante track, Serra do Japi.

\begin{tabular}{|c|c|c|c|c|c|c|c|}
\hline & Jan & Feb & Apr & Jun & Aug & Oct & Dec \\
\hline Undamaged (\%) & $53(51.9)$ & $59(52.7)$ & $86(72.3)$ & $43(51.8)$ & 37 (64.9) & 0 & $12(13.0)$ \\
\hline Trupanea sp. (\%) & $17(16.7)$ & $3(2.7)$ & $17(14.3)$ & $3(3.6)$ & $1(1.7)$ & $1(2.5)$ & $5(6.5)$ \\
\hline Melanagromyza sp. (\%) & $22(21.6)$ & $44(39.3)$ & $13(10.9)$ & $11(13.25)$ & $16(28.1)$ & $27(67.5)$ & $33(42.8)$ \\
\hline Geometridae spp. (\%) & $9(8.8)$ & $5(4.5)$ & $2(1.7)$ & $23(27.7)$ & $3(5.3)$ & $10(25.0)$ & $14(18.2)$ \\
\hline Co-occurrence of herbivores (\%) & $1(1.0)$ & $1(0.9)$ & $1(0.8)$ & $3(3.6)$ & 0 & $2(5.0)$ & $13(16.9)$ \\
\hline
\end{tabular}


compared to the other categories, varied along the seasons $\left(\mathrm{F}_{6,590}=3.68 ; \mathrm{P}=0.001\right)$, and was more pronounced in December. The higher number of damaged achenes occurred in unfertilized relative to fertilized ovules (figure 2).

The proportion of flowers with stigmas damaged by Geometridae spp. varied seasonally $\left(\mathrm{F}_{6,590}=6.65\right.$; $\mathrm{P}<0.0001$ ), being higher in June and August and lower in December (figure 3).

Effects of herbivory on the ovule fertilization - In April and December there was a higher proportion of fertilized-undamaged ovules in non-infested capitula (t-test; April: $\mathrm{t}=3.72,117 \mathrm{df}, \mathrm{P}<0.001$; December: $\mathrm{t}=-3.43,75 \mathrm{df}, \mathrm{P}<0.001$, figure 4 ). Nevertheless, in January, February, June and August,

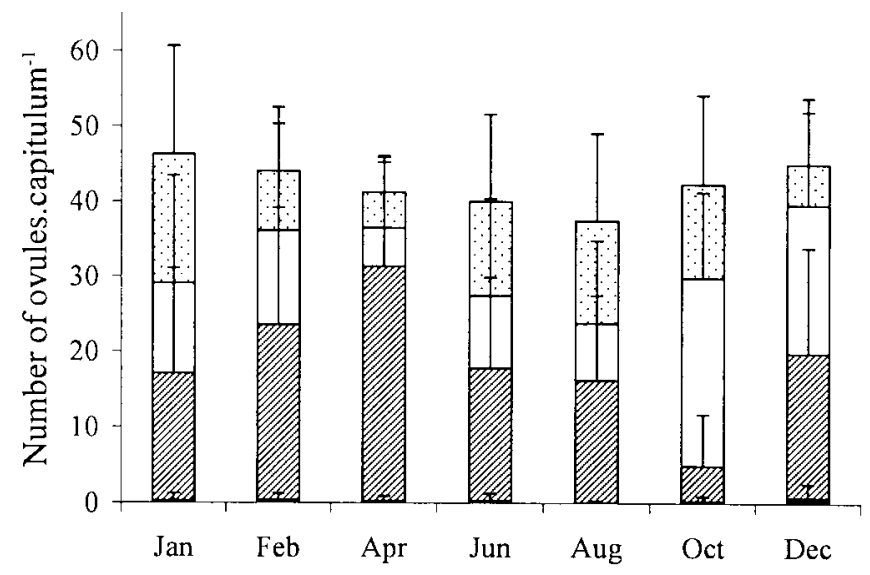

Figure 2. Mean (+ SD) number of ovules per capitulum of Trichogoniopsis adenantha, in 1999, in Mirante track, Serra do Japi. Categories: fertilized-damaged (ם), fertilizedundamaged ( $\square$ ), unfertilized damaged (ש) and unfertilized undamaged ovules $(\square)$.

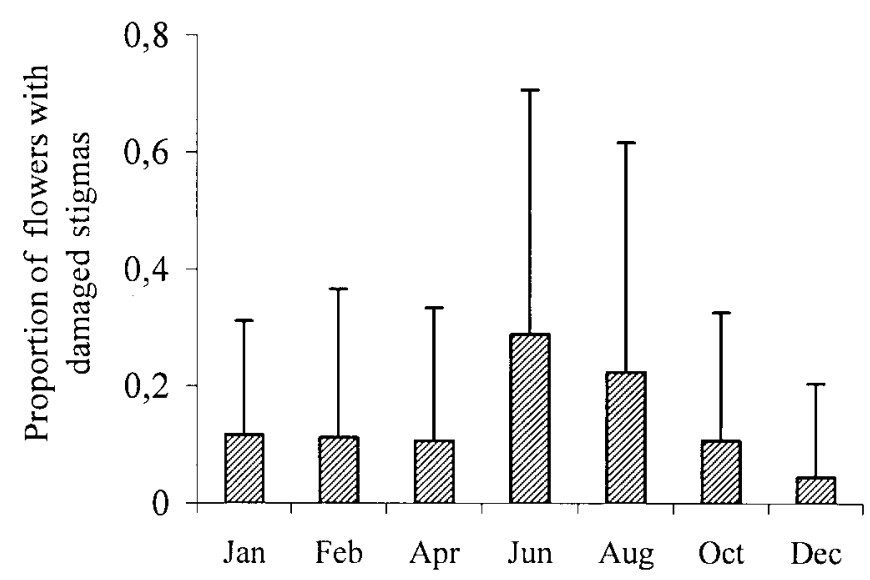

Figure 3. Mean (+ SD) of the proportion of Trichogoniopsis adenantha's flowers with damaged stigmas produced by Geometridae spp. larvae divided by the total of open flowers, in Mirante track, Serra do Japi.

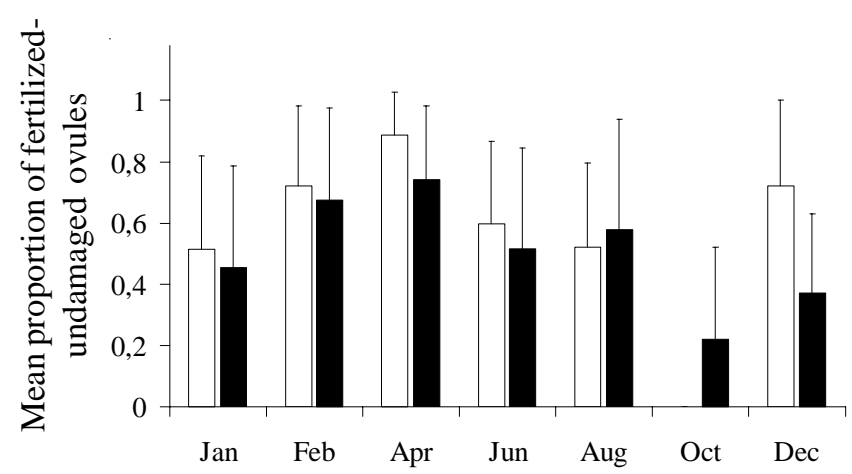

Figure 4. Mean (+ SD) of the proportion of Trichogoniopsis adenantha's fertilized-undamaged ovules by the total of undamaged achenes (fertilized + unfertilized), in non-infested $(\square)$ and infested capitula ( $\square$ ), in Mirante track, Serra do Japi. There was no non-infested capitula in October.

there was no significant difference in the proportion of fertilized-undamaged ovules between infested and non-infested capitula ( $\mathrm{P} \geq 0.2$ ). The relationship between proportion of flowers with damaged stigmas and the proportion of undamaged, unfertilized ovule was positive and significant only in August $(r=0.41$; $\mathrm{P}=0.010 ; \mathrm{n}=37$ ).

\section{Discussion}

Floral phenology and seasonal fluctuation of the arthropods - Although Trichogoniopsis adenantha population flowered over time, there were more reproductive branches and capitula in the rainy period, with a peak between March and April. This implies an unimodal pattern, with two distinct phases of development: a reproductive phase in the rainy period and a vegetative phase in the dry period. Similar phenological pattern was already observed for other plant species in the study area (Morellato et al. 1990, Morellato \& Leitão Filho 1990, 1992). Since the reproductive branches of $T$. adenantha correlated with rainfall and temperature, we suggest that these factors are crucial in modeling the plant phenological pattern. In the same way, the achene production increased almost instantaneously, with a rise in water availability. Generally, precipitation is the source for almost all soil moisture available for plants, which will be used to produce leaves, flowers and seeds (e.g. McKenna \& Houle 2000). Moreover, the water in the soil makes minerals soluble and available to the plants (Campo et al. 1998). Trichogoniopsis adenantha was apparently the unique plant species that flower throughout the entire 
year in the study site (Romero \& Vasconcellos Neto 2003, 2004a, b), and this was very important for the maintenance of arthropods of several guilds during unsuitable periods. Romero \& Vasconcellos Neto (2003, $2004 \mathrm{a}$, b) suggested that the spider Misumenops argenteus (Thomisidae) choose T. adenantha branches to forage because of the constant production of inflorescences (capitula), which attract prey along all seasonal periods.

In general, the arthropod abundance on T. adenantha was higher in the summer (December to April), when the rainfall was highest and the branches flowered. Populations of insects that feed on plants are generally synchronized with food abundance, and with environmental conditions such as temperature and moisture (Wolda 1978, 1988, Tanaka \& Tanaka 1982). Moreover, phytophagous insects, especially endophages, are negatively affected by the plant stress under extreme drought conditions (e.g. Waring \& Price 1990). Nevertheless, in the present study, the predator Reduviidae sp. occurred in great density during the dry, cold period, with a peak in July. This bug foraged on leaves of new branches (without capitula), and was never seen using capitula as foraging sites. Since in the period in which this species occurred there were more foraging sites (new branches), the pattern of seasonal fluctuation observed was probably adaptative.

Infestation rates and viable achene production Despite the principal herbivores have occurred in higher frequency during the flowering peak of T. adenantha (March-April), they infested proportionally less capitula, and damaged less achene and stigmas in this period (April). In principle, these results seem to be contradictory, however, in April there were much more reproductive branches and capitula, suggesting that the availability of capitula was larger than the herbivore demand. This synchrony between capitula production and herbivorous insects may function as a defensive strategy of the plant to compensate herbivory, producing capitula in such a number that exceeds the demand and satiates its herbivores. In October, as the number of reproductive branches and capitula decreased, the availability of food resources for herbivores also decreased, which meant that, proportionally, more capitula were infested and achenes were damaged in higher number. In this month, the capitula infestation rate was, in fact, $100 \%$. In December, there was also a high rate of total damaged achenes, which can be explained by the rise in the number of endophage herbivores followed by the proportional low quantity of capitula available.
Possibly, this low availability of capitula caused the observed higher frequency of herbivore co-occurrence, which damaged fertilized ovules. These ovules are hardier than those unfertilized (G.Q. Romero, unpublished data), and probably in the co-occurrence, the herbivores run out the more suitable resource (unfertilized ovules) and change to feed on fertilized ovules.

The observed pattern of seasonal variation in ovule fertilization is in synchrony with the seasonal fluctuation of the floral visitors. The principal floral visitors of Trichogoniopsis adenantha, the butterflies of the subfamily Ithomiinae, occurred in higher frequency in the rainy season (January to May), as also recorded by Vasconcellos Neto (1991) and Brown Junior (1992). In October, these ithomiinaes probably are aggregated in masses (Vasconcellos Neto 1991), perhaps distant from the study area. Ithomiinaes use Asteraceae flowers as a food source and to sequester pyrrolizidine alkaloids as anti-predation defenses (Trigo 2000). Thrips (Thysanoptera), which occur in a high frequency in T. adenantha capitula (G.Q. Romero, unpublished data) and are considered as the main agents for the fertilization of some Asteraceae species (from $50 \%$ to $65 \%$ of fertilized ovules) (Ananthakrishnan 1993), may be important for the fertilization of some $T$. adenantha ovules when the butterflies and other floral visitors are absent or in low density (June-December).

Effects of herbivory on the ovule fertilization - In April and December, there was a higher mean proportion of fertilized-undamaged ovules in non-infested capitula compared to infested capitula. This finding is a strong indication that floral herbivory affects indirectly the ovule fertilization. Pollinators may avoid infested capitula because of the smaller number of viable flowers per capitula that have, consequently, less pollen and nectar. There is evidence that pollinators avoid damaged flowers (Lehtilä \& Strauss 1997, Krupnick et al. 1999, Mothershead \& Marquis 2000). Alternatively, thrips, which may play an important role in $T$. adenantha ovule fertilization, may avoid occupying damaged capitula and/or those with endophages, which may be potential predators or competitors for space inside the capitula. Other evidences from the phenological patterns of seed set reinforce the hypothesis of the indirect effect of the herbivory on ovule fertilization: T. adenantha produced a quantity of capitula that exceed the herbivore demand in April (as discussed above), and because of this, several others became undamaged and attractive to pollinators. In October, since the plants had all their 
capitula infested by endophages, the herbivory may have indirectly affected the ovule fertilization.

The correlation between the proportion of intact, non-fertilized ovules and the proportion of flowers with damaged stigmas indicates that herbivory of stigmas may have a direct effect on ovule fertilization. In this case, ovules were not fertilized, perhaps because there was no formation of the pollen tube, or because it was destroyed by herbivory.

In conclusion, rainfall was an important abiotic factor that modeled the phenological pattern of T. adenantha. With the rain, the plants produced more capitula that attracted more arthropods (pollinators and herbivores), indicating a strong bottom-up force affecting this plant-arthropod system (see also Romero \& Vasconcellos Neto 2003). As a possible strategy against seed predators, T. adenantha invested in a great quantity of capitula in April with a double benefit: satiate the herbivores that consequently left more uninfested capitula, which are more attractive to pollinators. Consequently, the largest number of undamaged, fertilized (viable) ovules and seed primordia was produced in April. Herbivory affected directly the ovule fertilization by possibly damaging stigmas and impeding the formation of the pollen tube, and indirectly by making the capitula less attractive to pollinators.

Acknowledgments - The authors thank T.M. Lewinsohn, J.E.C. Figueira, M.A. Garcia, A.V. Freitas, E. Ramires and two anonymous referees for advice and for reviewing the manuscript. A.M. de Almeida and T.M. Lewinsohn for providing information on T. adenantha endophagous insect relationships, and the staff of the "Base Ecológica da Serra do Japi" for logistic support in the field. This work was part of a MSc Thesis by G.Q. Romero, and was funded by a research grant from the Fapesp (Process 98/15854-3). $\mathrm{J}$. Vasconcellos Neto was supported by a grant from the $\mathrm{CNPq}$ (Process 300539/94-0).

\section{References}

ANANTHAKRISHNAN, T.N. 1993. The role of thrips in pollination. Current Science 65:262-264.

BROWN JUNIOR, K.S. 1992. Borboletas da Serra do Japi: diversidade, habitats, recursos alimentares e variação temporal. In História Natural da Serra do Japi: Ecologia e Preservação de uma Área Florestal no Sudeste do Brasil (L.P.C. Morellato, org.). Editora da Unicamp, Campinas, p.142-186.

CABRERA, L. \& DIERINGER, G. 1992. Reproductive biology of a population of Acourtia runcinata (Asteraceae, Mutisieae) at the northeastern limit of its range. American Midland Naturalist 128:83-88.
CALVO IRABIÉN, L.M. \& ISLAS LUNA, A. 1999. Predispersal predation of an understory rainforest herb Aphelandra aurantiaca (Acanthaceae) in gaps and mature forest. American Journal of Botany 86:1108-1113.

CAMPO, J., JARAMILLO, V.J. \& MAASS, J.M. 1998. Pulses of soil phosphorus availability in a Mexican tropical dry forest: effects of seasonality and level of wetting. Oecologia 115:167-172.

EHLERS, B.K. 1999. Variation in fruit set within and among natural populations of the self-incompatible herb Centaurea scabiosa (Asteraceae). Nordic Journal of Botany 19:653-663.

EHRLÉN, J. 1996. Spatiotemporal variation in predispersal seed predation intensity. Oecologia 108:708-713.

GREIG, N. 1993. Predispersal seed predation of five Piper species in tropical rainforest. Oecologia 93:412-420.

HAMILTON, J.G., HOLZAPFEL, C. \& MAHALL, B.E. 1999. Coexistence and interference between a native perennial grass and non-native annual grasses in California. Oecologia 121:518-526.

JANZEN, D.H. 1971. Seed predation by animals. Annual Review of Ecology and Systematics 2:465-492.

KRUPNICK, G.A., WEIS, A.E. \& CAMPBELL, D.R. 1999. The consequences of floral herbivory for pollinator service to Isomeris arborea. Ecology 80:125-134.

LEHTILÄ, K. \& STRAUSS, S.Y. 1997. Leaf damage by herbivores affects attractiveness to pollinators in wild radish, Raphanus raphanistrum. Oecologia 111:396-403.

LEITÃO FILHO, H.F. 1992. A flora arbórea da Serra do Japi. In História Natural da Serra do Japi: Ecologia e Preservação de uma Área Florestal no Sudeste do Brasil (L.P.C. Morellato, org.). Editora da Unicamp, Campinas, p. 40-62.

LOUDA, S.M. 1982. Limitation of the recruitment of the shrub Haplopappus squarrosus (Asteraceae) by flower- and seed-feeding insects. Journal of Ecology 70:43-53.

LOUDA, S.M. \& POTVIN, M.A. 1995. Effect of inflorescencefeeding insects on the demography and lifetime fitness of a native plant. Ecology 76:229-245.

MADDOX, D.M., JOLEY, D.B., MAYFIELD, A. \& MACKEY, B.E. 1991. Impact of Bangasternus orientalis (Coleoptera: Curculionidae) on achene production of Centaurea solstitialis (Asterales, Asteraceae) at a low and high elevation site in California. Environmental Entomology 20:335-337.

MAMOOD, A.N., RAY, D.T. \& WALLER, G.D. 1990. Seed set in Guayule (Parthenium argentatum, Asteraceae) in relation to insect pollination. Economic Botany 44:440-444.

MCKENNA, M.F. \& HOULE, G. 2000. Why are annual plants rarely spring ephemerals? New Phytologist 148:295-302.

MORELLATO, L.P.C. \& LEITÃO FILHO, H.F. 1990. Estratégias fenológicas de espécies arbóreas de floresta mesófila na Serra do Japi, Jundiaí, São Paulo. Revista Brasileira de Biologia 50:163-173. 
MORELLATO, L.P.C. \& LEITÃO FILHO, H.F. 1992. Padrões de frutificação e dispersão na Serra do Japi. In História Natural da Serra do Japi: Ecologia e Preservação de uma Área Florestal no Sudeste do Brasil (L.P.C. Morellato, org.). Editora da Unicamp, Campinas, p. 112-140.

MORELLATO, L.P.C., LEITÃO FILHO, H.F. RODRIGUES, R.R. \& JOLY, C.A. 1990. Estratégias fenológicas de espécies arbóreas de floresta de altitude na Serra do Japi, Jundiaí, São Paulo. Revista Brasileira de Biologia 50:149-162.

MOTHERSHEAD, K. \& MARQUIS, R.J. 2000. Fitness impacts of herbivory through indirect effects on plant-pollinator interactions in Oenothera macrocarpa. Ecology 81:30-40.

OGDEN, J. \& POWELL, J.A. 1979. A quantitative description of the forest vegetation on an altitudinal gradient in the Mount Field National Park, Tasmania, and a discussion of its history and dynamics. Australian Journal of Ecology 4:293-325.

OLSEN, K.M. 1997. Pollination effectiveness and pollinator importance in a population of Heterotheca subaxillaris (Asteraceae). Oecologia 109:114-121.

PILSON, D. 2000. Herbivory and natural selection on flowering phenology in wild sunflower, Helianthus annuus. Oecologia 122:72-82.

PINTO, H.S., 1992. Clima na Serra do Japi. In História Natural da Serra do Japi: Ecologia e Preservação de uma Área Florestal no Sudeste do Brasil (L.P.C. Morellato, org.). Editora da Unicamp, Campinas, p. 30-38.

ROITMAN, G.G. 1999. Pollination biology of Grindelia covasii (Asteraceae), a potential crop for arid lands. Journal of Arid Environments 43:103-110.

ROMERO, G.Q. \& VASCONCELLOS NETO, J. 2003. Natural history of Misumenops argenteus (Thomisidae): seasonality and diet on Trichogoniopsis adenantha (Asteraceae). Journal of Arachnology 31:297-304.
ROMERO, G.Q. \& VASCONCELLOS-NETO, J. 2004a. Foraging by the flower-dwelling spider, Misumenops argenteus (Thomisidae), at high prey density sites. Journal of Natural History 38:1287-1296.

ROMERO, G.Q. \& VASCONCELLOS-NETO, J. $2004 \mathrm{~b}$. Beneficial effects of flower-dwelling predators on their host plant. Ecology 85:446-457.

SHEPPARD, A.W., CULLEN, J.M. \& AESCHLIMANN, J.P. 1994. Predispersal seed predation on Cardus nutans (Asteraceae) in southern Europe. Acta Oecologica 15:529-541.

STEPHENSON,A.G. 1981. Flower and fruit abortion: proximate causes and ultimate functions. Annual Review of Ecology and Systematics 12:253-279.

TANAKA, L.K. \& TANAKA, S.K. 1982. Rainfall and seasonal changes in arthropod abundance on a tropical oceanic island. Biotropica 14:114-123.

TRIGO, J.R. 2000. Chemistry of defense against predation in neotropical Lepidoptera: facts, perspectives and caveats. Journal of Brazilian Chemical Society 11:551-561.

VASCONCELOS NETO, J. 1991. Interactions between Ithomiine butterflies and Solanaceae: feeding and reproductive strategies. In Plant-Animal Interactions. Evolutionary Ecology in Tropical and Temperate Regions (P.W. Price, T.M. Lewinsohn, G.W. Fernandes \& W.W. Benson, eds.). John Wiley and Sons, New York, p.291-313.

WARING, G.L. \& PRICE, P.W. 1990. Plant water stress and gall formation (Cecidomyiidae: Asphondylia spp.) on creosote bush. Ecological Entomology 15:87-95

WOLDA, K. 1978. Seasonal fluctuations in rainfall, food and abundance of tropical insects. Journal of Tropical Ecology 47:369-381.

WOLDA, K. 1988. Insect seasonality: why? Annual Review of Ecology and Systematics 19:1-18.

ZAR, J.H. 1996. Biostatistical Analysis. Prentice Hall, New Jersey. 